\title{
Targeting TNF-a: A novel therapeutic approach for asthma
}

\author{
Christopher Brightling, PhD, MRCPa, Mike Berry, MD, MRCPb ${ }^{b}$ and Yassine Amrani, PhD ${ }^{a}$ \\ Leicester and Birmingham, United Kingdom \\ anstitute of Lung Health, University of Leicester, Edgbaston, Birmingham \\ bUniversity of Birmingham, Edgbaston, Birmingham
}

\section{Abstract}

\begin{abstract}
Approximately $5 \%$ to $10 \%$ of patients with asthma have severe disease that is refractory or poorly responsive to inhaled corticosteroid therapy. These patients represent an important unmet clinical need because they experience considerable morbidity and mortality and consume a disproportionately large amount of health care resources. TNF-a is a proinflammatory cytokine that has been implicated in many aspects of the airway pathology in asthma. Evidence is emerging to suggest that it might play an important role in severe refractory disease. The development of novel TNF-a antagonists has allowed us to test the role of this cytokine in vivo. Preliminary studies have demonstrated an improvement in asthma quality of life, lung function, and airway hyperresponsiveness and a reduction in exacerbation frequency in patients treated with anti-TNFa therapy. However, there is marked heterogeneity in response, suggesting that benefit is likely to be reserved to a small subgroup. Importantly, where efficacy is reported, this also needs to be considered in the context of concerns about the safety of anti-TNF-a therapies. Therefore the challenge for clinicians is to evaluate the risk/benefit ratio of these therapies in individual patients with asthma.
\end{abstract}

\section{Keywords}

Asthma; refractory asthma; TNF-a; mast cells; airway smooth muscle

\begin{abstract}
Asthma is a common disease that is increasing in prevalence worldwide. ${ }^{1}$ Its prevalence is highest in industrialized countries, where it affects about $15 \%$ of the adult population. ${ }^{2}$ The mainstay of therapy is inhaled corticosteroids, and the majority of asthma symptoms are controlled with inhaled corticosteroids alone or in combination with long-acting $\beta$-agonists. ${ }^{3}$ However, $5 \%$ to $10 \%$ of the asthmatic population have severe refractory disease. ${ }^{4-6}$ This group is important because they are responsible for a disproportionate share of the health
\end{abstract}

(C) 2008 American Academy of Allergy, Asthma \& Immunology

Reprint requests: Christopher Brightling, PhD, MRCP, Institute of Lung Health, University of Leicester, Leicester, LE3 9QP, United Kingdom.ceb17@le.ac.uk.

Disclosure of potential conflict of interest: C. Brightling has consulting arrangements with Cambridge Antibody Technology, GlaxoSmithKline, AstraZeneca, Pfizer, Roche, and Piramed; owns stock in Leicester AIR; has received grant support from AstraZeneca, Cambridge Antibody Technology, and GlaxoSmithKline; and is on the speakers' bureau for AstraZeneca and GlaxoSmithKline. Y. Amrani has received grant support from Centocor and the National Institutes of Health. M. Berry has declared that he has no conflict of interest. 
care costs and morbidity associated with this disease. This group of patients represents a significant unmet need, and novel therapies are urgently required.

Evidence supports a role for anti-TNF- $a$ as a potential new therapy in severe refractory asthma. ${ }^{7,8}$ Initial enthusiasm fueled by these early studies has been dampened by concerns over safety, ${ }^{9}$ and its efficacy is likely to be confined to a small subgroup of patients with severe asthma. There is an increasing recognition that there is considerable phenotypic heterogeneity in severe refractory asthma, ${ }^{10,11}$ and it is therefore perhaps predictable that the efficacy of novel specific therapies will be limited to subphenotypes.

In this review we acknowledge the importance of heterogeneity in asthma, summarize the biology of TNF- $a$ with particular reference to its role in asthma and the development of airway hyperresponsiveness (AHR), and review the findings of currently published clinical trials of anti-TNF-a therapy in asthma.

\section{TNF-a BIOLOGY AND SIGNALING}

TNF- $a$ is the most widely studied pleiotropic cytokine of the TNF superfamily. TNF- $a$ is an important cytokine in the innate immune response, which plays a key role in the immediate host defense against invading microorganisms before activation of the adaptive immune system. ${ }^{12}$ It is principally produced by macrophages in response to activation of membranebound pattern-recognition molecules, such as Toll-like receptors, which detect common bacterial cell-surface products, such as LPSs. TNF- $a$ is also produced by several other proinflammatory cells, including monocytes, dendritic cells, B cells, $\mathrm{CD}^{+}{ }^{+}$cells, neutrophils, mast cells and eosinophils, and the structural cells (ie, fibroblasts, epithelial cells, and smooth muscle cells). ${ }^{13}$ TNF-a is initially produced as a biologically active, 26$\mathrm{kd}$, membrane-anchored precursor protein (membrane TNF-a [mTNF-a]), ${ }^{14}$ which is subsequently cleaved by TNF-a-converting enzyme ${ }^{15}$ to release the 17 -kd free protein. These proteins form biologically active homotrimers ${ }^{16}$ that act on the ubiquitously expressed TNF-a receptors 1 and $2 .{ }^{17}$ This receptor-ligand interaction causes intracellular signaling without internalization of the complex, leading to phosphorylation of I $\mathrm{KBa}$ and thus activation of the nuclear factor $\mathrm{\kappa B}$ ( $\mathrm{p} 50-\mathrm{p} 65)$ heterodimer, which then interacts with the DNA chromatin structure to increase transcription of proinflammatory genes, such as ILIB, $I L 6, I L 8$, and TNFA itself. The response to TNF-a activation is balanced by shedding of the extracellular domain of the TNF-a receptors. The mechanisms involved in TNF-a biology and signaling are summarized in Fig 1.

\section{ROLE OF TNF-a IN THE ASTHMA PARADIGM}

TNF- $a$ has been implicated in the pathophysiologic mechanisms of several chronic inflammatory diseases, including inflammatory bowel disease and rheumatoid arthritis. ${ }^{18} \mathrm{In}$ patients with rheumatoid disease, antagonism of TNF-a through treatment with either recombinant soluble receptors or neutralizing antibodies leads to improvement in disease activity scores. ${ }^{19}$ Similarly, positive results are seen after treatment of other conditions that are thought to be mediated by TNF-a. 
The possibility that TNF- $a$ contributes to the inflammatory response seen in the asthmatic airway is supported by observations that TNF- $a$ mRNA $^{20}$ and protein ${ }^{21}$ levels were increased in the airways of patients with asthma. Importantly, the administration of inhaled recombinant TNF- $a$ to normal subjects led to the development of AHR and airway neutrophilia. ${ }^{22,23}$ The mechanisms driving TNF-a-induced AHR have not been fully elucidated. AHR could be caused by a direct effect of TNF-a on airway smooth muscle (ASM), as outlined in detail below, or indirectly by the release of the cysteinyl leukotrienes $\mathrm{C}_{4}$ and $\mathrm{D}_{4} \cdot{ }^{24}$ In addition to its effects on AHR, TNF- $a$ has several other actions that might be relevant to asthma. TNF- $a$ is a chemoattractant for neutrophils and eosinophils, ${ }^{25}$ increases the cytotoxic effect of eosinophils on endothelial cells, ${ }^{26}$ is involved in the activation of T cells, ${ }^{27}$ and increases epithelial expression of adhesion molecules, such as intercellular adhesion molecule 1 and vascular cell adhesion molecule $1 .^{28}$ The upregulation of adhesion molecules might also promote migration of inflammatory cells to the lung and therefore indirectly affect the development of AHR ${ }^{29}$ In addition to its relevance to asthma in general, TNF-a has several properties that might be relevant to severe refractory asthma, including recruitment of neutrophils, ${ }^{22}$ induction of glucocorticoid resistance, ${ }^{30}$ myocyte proliferation, ${ }^{31}$ and stimulation of fibroblast growth and maturation into myofibroblasts by promoting TGF- $\beta$ expression. ${ }^{32,33}$ Therefore in severe refractory asthma, in addition to promoting airway inflammation and AHR, TNF-a might play a central role in airway remodeling. The role of TNF- $a$ in the development of several characteristics of the asthma paradigm is summarized in Fig 2.

\section{DIRECT MODULATION OF ASM CONTRACTILE FUNCTION BY MAST CELL-DERIVED TNF- $a$ : AN EMERGING MECHANISM INVOLVED IN AHR IN ASTHMA}

A novel aspect of asthma pathogenesis has been uncovered by the observation that mast cells are localized within the ASM bundle in patients with asthma. ${ }^{34-37}$ Mast cell number correlated positively with the degree of $\mathrm{AHR}^{34}$ and with the bronchoconstrictor response to a deep inspiration, ${ }^{38}$ suggesting that mast cell-ASM cell interactions are likely to be central in the development of the disordered physiology in asthma. The strength of this assertion was underpinned by the paucity of mast cells within the ASM bundle in patients with eosinophilic bronchitis. This is a condition that presents with chronic cough and shares many of the immunopathologic features of asthma but is not associated with airflow obstruction or AHR. ${ }^{34,39-41}$ One postmortem study of fatal and nonfatal asthma has shown that there was a marked increase in mast cell degranulation in the ASM bundle in both the large and small airways, ${ }^{42}$ and another demonstrated that increased numbers of mast cells (degranulated and intact) are associated with increased ASM shortening in fatal asthma, ${ }^{43}$ suggesting that mast cell infiltration is also an important component of the progression of the disease. Mast cells are the major source of TNF- $a$ in the airways. Therefore it is likely that the close proximity of these cells will facilitate mast cell-derived TNF-a activation of ASM and contribute to the development of AHR.

A number of lines of evidence support the view that TNF-a-induced AHR is mediated by direct effects on ASM. Early studies performed in guinea pig ${ }^{44}$ and ovine ${ }^{45}$ tracheal tissues 
demonstrated that incubation with TNF- $a$ increased the contractile responses to methacholine. Similarly, murine isolated tracheal rings incubated with TNF-a became hyperresponsive to additional $\mathrm{G}$ protein-coupled receptor agonists, including carbachol, ${ }^{46}$ bradykinin, ${ }^{47}$ and serotonin. ${ }^{48}$ Only 2 studies, possibly because of the difficulty in obtaining and working with human tissues, showed that TNF- $\alpha$ alone or in combination with IL-1 $\beta$ exerted similar effects in human bronchi by enhancing electric field stimulation- or acetylcholine-associated contractile responses. ${ }^{49,50}$ Therefore TNF-a can promote a hypercontractile phenotype in isolated ASM to a variety of bronchoconstrictor agonists.

The pathways by which TNF-a modulates the contractility of ASM have not been clearly established, but possibilities include changes in receptor expression, affinity for bronchoconstrictor, or both ${ }^{47}$; impaired response to bronchorelaxant agonists ${ }^{46}$; and alteration in calcium influx or altered calcium sensitivity. ${ }^{51}$ These are summarized in Fig 3. We and now others identified that TNF-a potentiated calcium signals in response to different $\mathrm{G}$ protein-coupled receptor agonists. ${ }^{52} \mathrm{Ca}^{2+}$ plays a central role in regulating ASM contractile function. Therefore it is likely that alterations in $\mathrm{Ca}^{2+}$ regulatory mechanisms induced by TNF-a will lead to impaired ASM contractility. The small monomeric G protein RhoA can enhance ASM contractility to any agonists by increasing levels of myosin light chain phosphorylation through the Rho-activated kinase-dependent suppression of myosin light chain phosphatase. ${ }^{53}$ Importantly, this Rho-dependent calcium sensitization can be activated by TNF- $a .{ }^{54}$ An alternative mechanism by which TNF- $a$ can modulate calcium sensitivity is through the upregulation of $\mathrm{CD} 38$, an ectoenzyme that stimulates calcium signaling. ${ }^{55,56}$ This effect is modulated by IFN- $\beta$ (Amrani Y, unpublished observations), which we have previously reported to regulate the inflammatory responses of the ASM treated with TNF-a. ${ }^{57,58}$

These different studies lead to several conclusions: (1) TNF-a enhanced in vitro ASM responsiveness to a variety of different contractile agonists, an observation that closely resembles the in vivo manifestation of AHR; (2) the effects of TNF-a are confirmed in both human and animal species; (3) TNF- $a$ action results in either augmenting ASM reactivity characterized by an upward shift of the dose-response curve (called hyperreactivity), increased ASM sensitivity evidenced by a leftward shift of the curve (also called hypersensitivity or excitability), or both; and (4) the underlying mechanisms by which TNFa plays a role of in AHR are complex and poorly understood, but experimental evidence tends to implicate an alteration of the ASM at 2 molecular levels: calcium signaling, Rhodependent increased sensitivity of the calcium apparatus to calcium, or both.

\section{UPREGULATED TNF- $a$ AXIS IS A FEATURE OF SEVERE REFRACTORY ASTHMA}

The view that TNF-a might be of particular relevance in severe refractory asthma is supported by expression studies that have included this group of asthmatic patients. Howarth et $\mathrm{al}^{7}$ reported that TNF- $a$ concentration in bronchoalveolar lavage fluid and TNF- $a$ protein and mRNA expression in bronchial biopsy specimens were increased in patients with severe asthma compared with expression in those with mild disease. We found that increased expression of mTNF- $a$ and TNF- $a$ receptor 1 in peripheral blood assessed by means of flow 
cytometry was only noted in patients with severe disease. ${ }^{8}$ Thus upregulation of TNF-a is a feature associated with severe refractory disease, suggesting that this phenotype might be particularly responsive to anti-TNF- $a$ therapies.

\section{CLINICAL TRIALS OF ANTI-TNF-a THERAPY IN ASTHMA}

A number of strategies to block the TNF-a axis are available, including infliximab (a chimeric mouse/humanized $\mathrm{mAb}$ ), etanercept (a soluble fusion protein combining 2 p75 TNF receptors with an Fc fragment of human IgG1), and adalimumab (a fully human mAb). Clinical trials in asthma of anti-TNF-a therapy are summarized in Table $\mathrm{I}^{7,8,59-61}$

Enthusiasm for anti-TNF- $a$ in severe asthma was first derived from an uncontrolled study of etanercept for 12 weeks in patients with severe (Global Initiative for Asthma stage V) asthma. Howarth et $\mathrm{al}^{7}$ reported a significant (2.5 doubling concentration) improvement in methacholine AHR, a 240-mL improvement in $\mathrm{FEV}_{1}$, and an improvement in asthma quality of life. These findings were replicated in a randomized, placebo-controlled study in which 10 weeks of treatment with etanercept led to a similar improvement in $\mathrm{PC}_{20}$ and $\mathrm{FEV}_{1}$, as well as an improvement in asthma-related quality of life. ${ }^{8}$ One of the most striking aspects of this study was that the clinical response correlated closely with the expression of mTNF$a$ and TNF- $a$ receptor 1 on monocytes. This suggests that measurement of TNF- $a$ expression in monocytes might be a useful biomarker of responsiveness but also suggests that anti-TNF-a approaches will only be effective in a subgroup of asthmatic patients. Another interesting aspect of the study was that there was no effect of etanercept therapy on the number of sputum eosinophils or neutrophils, but there was a reduction in sputum histamine concentration. One intriguing possible explanation for this apparent lack of effect on airway inflammation by anti-TNF-a in contrast to a marked effect on AHR is that TNFa derived from mast cells within the ASM bundle might play a critical role in the development of AHR. Similar beneficial effects, albeit less profound, have been reported in patients with moderate asthma. Erin et al ${ }^{59}$ performed a randomized placebo-controlled study with infliximab in patients with moderate asthma. No improvement in morning peak flow occurred with infliximab, but there was an improvement in peak flow variability and a $50 \%$ reduction in the number of mild exacerbations encountered. The relatively poor effect on lung function in this study might reflect either the selection of patients with less severe disease or a therapeutic difference between etanercept and infliximab. In an earlier segmental allergen challenge study, anti-TNF- $a$ therapy had no effect on AHR. ${ }^{60}$

Preliminary data from another study of etanercept in patients with severe asthma demonstrated no beneficial effect, ${ }^{61}$ supporting the view that if anti-TNF- $a$ is to be effective in asthma, it will only be on a relatively small subgroup of patients, possibly defined by an increased TNF axis. To date, there is a paucity of published long-term studies of anti-TNF- $a$ in asthma. However, the authors are aware of 2 unpublished longer-term, randomized, placebo-controlled, parallel-group studies in patients with moderate-to-severe asthma, with the first using etanercept and the second using golimumab. These studies have questioned the efficacy of anti-TNF- $\alpha$ in asthma. The latter study included a total of 231 subjects treated with golimumab across 3 doses and 78 subjects treated with placebo. The study was terminated after 24 weeks by an independent safety-monitoring committee 
because there were no improvements in the primary outcomes (the number of severe exacerbations and lung function) or secondary outcomes. Subgroup analysis did suggest that benefit was observed in certain phenotypes, and further detailed analysis is eagerly awaited.

\section{ANTI-TNF-a: RISK/BENEFIT BALANCE IN ASTHMA}

The safety of biologic therapies in chronic disease has been questioned, and therefore even in patients in whom anti-TNF-a therapy has efficacy, this needs to be considered in light of the potential risks. A recent report on the administration of infliximab for 6 months in patients with chronic obstructive pulmonary disease showed no benefit and recorded 9 malignancies in 157 treated patients compared with 1 malignancy in 77 placebo-treated subjects, together with an increased risk of pneumonia. ${ }^{62}$ In the unpublished golimumab study, after 24 weeks of therapy, the incidence of malignancy was increased in the treatment groups compared with that seen in the placebo-treated group. Similarly, there has also been an excess of malignancy and infection reported in patients treated with anti-TNF-a for rheumatoid arthritis. ${ }^{9}$ Therefore clinicians need to be cognizant of the balance between benefit and risk in their patients on an individual basis, and it is likely that anti-TNF-a therapy will be valuable in the management of some patients with severe refractory asthma, albeit in a small select subphenotype.

\section{CONCLUSIONS}

In conclusion, TNF- $a$ is a potentially important cytokine in patients with asthma, in particular in those with severe refractory disease. There is a very strong biologic rationale to support a central role for TNF-a in the development of AHR and other features of the asthma paradigm. It is also plausible that mast cells localized within the ASM bundle might be a particularly important source of TNF-a. Preliminary studies on small numbers of patients have demonstrated an improvement in lung function, AHR, asthma quality of life, and exacerbation rate after treatment with anti-TNF therapy. However, whether these findings are consistently reproducible has been questioned. Any potential efficacy also needs to be balanced against drug safety, particularly with respect to susceptibility to severe infection and the potential of solid organ malignancy. Heterogeneity in response to TNF-a antagonism is an important consideration, and the identification and further validation of biomarkers, such as mTNF-a expression, by peripheral blood monocytes need to be fully addressed in future studies.

\section{Acknowledgments}

Supported by Asthma UK, a DOH Clinician Scientist award, and NIH06364.

\section{Abbreviations used}

$\begin{array}{ll}\text { AHR } & \text { Airway hyperresponsiveness } \\ \text { ASM } & \text { Airway smooth muscle } \\ \text { mTNF-a } & \text { Membrane TNF-a }\end{array}$




\section{REFERENCES}

1. Bousquet J, Bousquet PJ, Godard P, Daures JP. The public health implications of asthma. Bull World health Organ. 2005; 83:548-54. [PubMed: 16175830]

2. Braman SS. The global burden of asthma. Chest. 2006; 130(suppl):4S-12S. [PubMed: 16840363]

3. [Accessed August 2007] Global Initiative for Asthma guidelines 11/06. Available at: http:// www.ginasthma.com

4. American Thoracic Society. Proceedings of the ATS workshop on refractory asthma: current understanding, recommendations, and unanswered questions. Am J Respir Crit Care Med. 2000; 162:2341-51. [PubMed: 11112161]

5. Moore WC, Peters SP. Severe asthma: an overview. J Allergy Clin Immunol. 2006; 117:487-94. [PubMed: 16522445]

6. Chanez P, Wenzel SE, Anderson GP, Anto JM, Bel EH, Boulet LP, et al. Severe asthma in adults: what are the important questions? J Allergy Clin Immunol. 2007; 119:1337-48. [PubMed: 17416409]

7. Howarth PH, Babu KS, Arshad HS, Lau L, Buckley M, McConnell W, et al. Tumour necrosis factor (TNFalpha) as a novel therapeutic target in symptomatic corticosteroid dependent asthma. Thorax. 2005; 60:1012-8. [PubMed: 16166100]

8. Berry MA, Hargadon B, Shelley M, Parker D, Shaw SE, Green RH, et al. Evidence of a role of tumor necrosis factor alpha in refractory asthma. N Engl J Med. 2006; 354:697-708. [PubMed: 16481637]

9. Bongartz T, Sutton AJ, Sweeting MJ, Buchan I, Matteson EL, Montori V. Anti-TNF antibody therapy in rheumatoid arthritis and the risk of serious infections and malignancies: systematic review and meta-analysis of rare harmful effects in randomized controlled trials. JAMA. 2006; 295:2275-85. [PubMed: 16705109]

10. Green RH, Brightling CE, Bradding P. The reclassification of asthma based on subphenotypes. Curr Opin Allergy Clin Immunol. 2007; 7:43-50. [PubMed: 17218810]

11. Wenzel SE. Asthma: defining of the persistent adult phenotypes. Lancet. 2006; 368:804-13. [PubMed: 16935691]

12. Medzhitov R, Janeway C Jr. Innate immunity. N Engl J Med. 2000; 343:338-44. [PubMed: 10922424]

13. Cazzola M, Polosa R. Anti-TNF-alpha and Th1 cytokine-directed therapies for the treatment of asthma. Curr Opin Allergy Clin Immunol. 2006; 6:43-50. [PubMed: 16505611]

14. Kriegler M, Perez C, DeFay K, Albert I, Lu SD. A novel form of TNF/cachectin is a cell surface cytotoxic transmembrane protein: ramifications for the complex physiology of TNF. Cell. 1988; 53:45-53. [PubMed: 3349526]

15. Zheng Y, Saftig P, Hartmann D, Blobel C. Evaluation of the contribution of different ADAMs to tumor necrosis factor alpha (TNFalpha) shedding and of the function of the TNFalpha ectodomain in ensuring selective stimulated shedding by the TNFalpha convertase (TACE/ADAM17). J Biol Chem. 2004; 279:42898-906. [PubMed: 15292243]

16. Smith RA, Baglioni C. The active form of tumor necrosis factor is a trimer. J Biol Chem. 1987; 262:6951-4. [PubMed: 3034874]

17. Brockhaus M, Schoenfeld HJ, Schlaeger EJ, Hunziker W, Lesslauer W, Loetscher H. Identification of two types of tumor necrosis factor receptors on human cell lines by monoclonal antibodies. Proc Natl Acad Sci U S A. 1990; 87:3127-31. [PubMed: 2158104]

18. Choy EH, Panayi GS. Cytokine pathways and joint inflammation in rheumatoid arthritis. N Engl J Med. 2001; 344:907-16. [PubMed: 11259725]

19. Olsen NJ, Stein CN. New drugs for rheumatoid arthritis. N Engl J Med. 2004; 350:2167-79. [PubMed: 15152062]

20. Ying S, Robinson DS, Varney V, Meng Q, Tsicopoulos A, Moqbel R, et al. TNF alpha mRNA expression in allergic inflammation. Clin Exp Allergy. 1991; 21:745-50. [PubMed: 1777835]

21. Bradding P, Roberts JA, Britten KM, Montefort S, Djukanovic R, Mueller R, et al. Interleukin-4, -5 , and -6 and tumor necrosis factor-alpha in normal and asthmatic airways: evidence for the 
human mast cell as a source of these cytokines. Am J Respir Cell Mol Biol. 1994; 10:471-80. [PubMed: 8179909]

22. Thomas PS, Yates DH, Barnes PJ. Tumor necrosis factor-alpha increases airway responsiveness and sputum neutrophilia in normal human subjects. Am J Respir Crit Care Med. 1995; 152:76-80. [PubMed: 7599866]

23. Thomas PS, Heywood G. Effects of inhaled tumour necrosis factor alpha in subjects with mild asthma. Thorax. 2002; 57:774-8. [PubMed: 12200521]

24. Huber M, Beutler B, Keppler D. Tumor necrosis factor alpha stimulates leukotriene production in vivo. Eur J Immunol. 1988; 18:2085-8. [PubMed: 2851448]

25. Lukacs NW, Strieter RM, Chensue SW, Widmer M, Kunkel SL. TNF-alpha mediates recruitment of neutrophils and eosinophils during airway inflammation. J Immunol. 1995; 154:5411-7. [PubMed: 7730642]

26. Slungaard A, Vercellotti GM, Walker G, Nelson RD, Jacob HS. Tumor necrosis factor alpha/ cachectin stimulates eosinophil oxidant production and toxicity towards human endothelium. J Exp Med. 1990; 171:2025-41. [PubMed: 1972179]

27. Scheurich P, Thoma B, Ucer U, Pfizenmaier K. Immunoregulatory activity of recombinant human tumor necrosis factor (TNF)-alpha: induction of TNF receptors on human T cells and TNF-alphamediated enhancement of T cell responses. J Immunol. 1987; 138:1786-90. [PubMed: 3029221]

28. Lassalle P, Delneste Y, Gosset P, Tonnel AB, Capron A. Potential implication of endothelial cells in bronchial asthma. Int Arch Allergy Appl Immunol. 1991; 94:233-8. [PubMed: 1682272]

29. Walter MJ, Morton JD, Kajiwara N, Agapov E, Holtzman MJ. Viral induction of a chronic asthma phenotype and genetic segregation from the acute response. J Clin Invest. 2002; 110:165-75. [PubMed: 12122108]

30. Franchimont D, Martens H, Hagelstein MY, Louis E, Dewe W, Chrousos GP, et al. Tumor necrosis factor alpha decreases, and interleukin-10 increases, the sensitivity of human monocytes to dexamethasone: potential regulation of the glucocorticoid receptor. J Clin Endocrinol Metab. 1999; 84:2834-9. [PubMed: 10443688]

31. Amrani Y, Panettieri RA Jr, Frossard N, Bronner C. Activation of the TNF alpha-p55 receptor induces myocyte proliferation and modulates agonist-evoked calcium transients in cultured human tracheal smooth muscle cells. Am J Respir Cell Mol Biol. 1996; 15:55-63. [PubMed: 8679222]

32. Desmouliere A, Geinoz A, Gabbiani F, Gabbiani G. Transforming growth factor-beta 1 induces alpha-smooth muscle actin expression in granulation tissue myofibroblasts and in quiescent and growing cultured fibroblasts. J Cell Biol. 1993; 122:103-11. [PubMed: 8314838]

33. Sullivan DE, Ferris M, Pociask D, Brody AR. Tumor necrosis factor-alpha induces transforming growth factor-beta1 expression in lung fibroblasts through the extracellular signal-regulated kinase pathway. Am J Respir Cell Mol Biol. 2005; 32:342-9. [PubMed: 15653932]

34. Brightling CE, Bradding P, Symon FA, Holgate ST, Wardlaw AJ, Pavord ID. Mast-cell infiltration of airway smooth muscle in asthma. N Engl J Med. 2002; 346:1699-705. [PubMed: 12037149]

35. Berger P, Girodet PO, Begueret H, Ousova O, Perng SW, Marthan R, et al. Tryptase-stimulated human airway smooth muscle cells induce cytokine synthesis and mast cell chemotaxis. FASEB J. 2003; 17:2139-41. [PubMed: 14500550]

36. Brightling CE. Chronic cough due to nonasthmatic eosinophilic bronchitis: ACCP evidence-based clinical practice guidelines. Chest. 2006; 129(suppl):116S-21S. [PubMed: 16428700]

37. Amin K, Janson C, Boman G, Venge P. The extracellular deposition of mast cell products is increased in hypertrophic airways smooth muscles in allergic asthma but not in nonallergic asthma. Allergy. 2005; 60:1241-7. [PubMed: 16134989]

38. Slats AM, Janssen K, van Schadewijk A, van der Plas DT, Schot R, van den Aardweg JG, et al. Bronchial inflammation and airway responses to deep inspiration in asthma and COPD. Am J Respir Crit Care Med. 2007; 176:121-8. [PubMed: 17379851]

39. Brightling CE, Symon FA, Birring SS, Bradding P, Wardlaw AJ, Pavord ID. Comparison of airway immunopathology of eosinophilic bronchitis and asthma. Thorax. 2003; 58:528-32. [PubMed: 12775868]

40. Brightling CE, Ward R, Goh KL, Wardlaw AJ, Pavord ID. Eosinophilic bronchitis is an important cause of chronic cough. Am J Respir Crit Care Med. 1999; 161:406-10. [PubMed: 10430705] 
41. Brightling CE. Chronic cough due to nonasthmatic eosinophilic bronchitis: ACCP evidence-based clinical practice guidelines. Chest. 2006; 129(suppl):116S-21S. [PubMed: 16428700]

42. Carroll NG, Mutavdzic S, James AL. Distribution and degranulation of airway mast cells in normal and asthmatic subjects. Eur Respir J. 2002; 19:879-85. [PubMed: 12030728]

43. Chen FH, Samson KT, Miura K, Ueno K, Odajima Y, Shougo T, et al. Airway remodeling: a comparison between fatal and nonfatal asthma. J Asthma. 2004; 41:631-8. [PubMed: 15584312]

44. Pennings HJ, Kramer K, Bast A, Buurman WA, Wouters EF. Tumour necrosis factor-alpha induces hyperreactivity in tracheal smooth muscle of the guinea-pig in vitro. Eur Respir J. 1998; 12:45-9. [PubMed: 9701413]

45. Reynolds AM, Holmes MD, Scicchitano R. Cytokines enhance airway smooth muscle contractility in response to acetylcholine and neurokinin A. Respirology. 2000; 5:153-60. [PubMed: 10894105]

46. Chen H, Tliba O, Van Besien CR, Panettieri RA Jr, Amrani Y. Selected contribution: TNF-a modulates murine tracheal rings responsiveness to G-protein-coupled receptor agonists and $\mathrm{KCl}$. J Appl Physiol. 2003; 95:864-72. [PubMed: 12730147]

47. Zhang Y, Adner M, Cardell LO. Up-regulation of bradykinin receptors in a murine in-vitro model of chronic airway inflammation. Eur J Pharmacol. 2004; 489:117-26. [PubMed: 15063163]

48. Adner M, Rose AC, Zhang Y, Sward K, Benson M, Uddman R, et al. An assay to evaluate the long-term effects of inflammatory mediators on murine airway smooth muscle: evidence that TNFalpha up-regulates 5-HT(2A)-mediated contraction. Br J Pharmacol. 2002; 137:971-82. [PubMed: 12429569]

49. Sukkar MB, Hughes JM, Armour CL, Johnson PR. Tumour necrosis factor-alpha potentiates contraction of human bronchus in vitro. Respirology. 2001; 6:199-203. [PubMed: 11555377]

50. Anticevich SZ, Hughes JM, Black JL, Armour CL. Induction of human airway hyperresponsiveness by tumour necrosis factor-alpha. Eur J Pharmacol. 1995; 284:221-5. [PubMed: 8549631]

51. Amrani Y, Bronner C. Tumor necrosis factor alpha potentiates the increase in cytosolic free calcium induced by bradykinin in guinea-pig tracheal smooth muscle cells. C R Acad Sci III. 1993; 316:1489-94. [PubMed: 8087627]

52. Amrani Y. Airway smooth muscle modulation and airway-hyperresponsiveness in asthma: new cellular and molecular paradigms. Exp Rev Clin Immunol. 2006; 2:353-64.

53. Amrani Y, Panettieri RA Jr. Modulation of calcium homeostasis as a mechanism for altering smooth muscle responsiveness in asthma. Curr Opin Allergy Clin Immunol. 2002; 2:39-45. [PubMed: 11964749]

54. Hunter I, Cobban HJ, Vandenabeele P, MacEwan DJ, Nixon GF. Tumor necrosis factor-alphainduced activation of RhoA in airway smooth muscle cells: role in the $\mathrm{Ca}(2+)$ sensitization of myosin light chain(20) phosphorylation. Mol Pharmacol. 2003; 63:714-21. [PubMed: 12606782]

55. Deshpande DA, Walseth TF, Panettieri RA Jr, Kannan MS. CD38-cyclic ADP-ribose-mediated Ca2+ signaling contributes to airway smooth muscle hyperresponsiveness. FASEB J. 2003; 17:452-4. [PubMed: 12514117]

56. Deshpande DA, White TA, Dogan S, Walseth TF, Panettieri RA Jr, Kannan MS. CD38/cyclic ADP-ribose signaling: role in the regulation of calcium homeostasis in airway smooth muscle. Am J Physiol Lung Cell Mol Physiol. 2005; 288:L773-88. [PubMed: 15821018]

57. Tliba O, Panettieri RA Jr, Tliba S, Walseth TF, Amrani Y. Tumor necrosis factor-alpha differentially regulates the expression of proinflammatory genes in human airway smooth muscle cells by activation of interferon-beta-dependent CD38 pathway. Mol Pharmacol. 2004; 66:322-9. [PubMed: 15266023]

58. Tliba O, Tliba S, Da Huang C, Hoffman RK, DeLong P, Panettieri RA Jr, et al. Tumor necrosis factor a modulates airway smooth muscle function via the autocrine action of interferon $\beta$. J Biol Chem. 2003; 278:50615-23. [PubMed: 14519761]

59. Erin EM, Leaker BR, Nicholson GC, Tan AJ, Green LM, Neighbour H, et al. The effects of a monoclonal antibody directed against tumor necrosis factor-alpha in asthma. Am J Respir Crit Care Med. 2006; 174:753-62. [PubMed: 16840747] 
60. Rouhani FN, Meitin CA, Kaler M, Miskinis-Hilligoss D, Stylianou M, Levine SJ. Effect of tumor necrosis factor antagonism on allergen-mediated asthmatic airway inflammation. Respir Med. 2005; 99:1175-82. [PubMed: 16085220]

61. Morjaria JB, Chauhan AJ, Bobu KS, Mehta RL, Smith S, North M, et al. Assessment of a soluble TNFalpha receptor fusion protein (etanercept) as a novel therapeutic agent for severe refractory asthma [abstract]. Proc Am Thorac Soc. 2006; 3:A16.

62. Rennard SI, Fogarty C, Kelsen S, Long W, Ramsdell J, Allison J, et al. On behalf of the COPD investigators: The safety and efficacy of infliximab in moderate to severe chronic obstructive pulmonary disease. Am J Respir Crit Care Med. 2007; 175:926-34. [PubMed: 17290043] 
Summary: In severe asthma, TNF-a expression is increased. Heterogeneity of the response and concerns over safety limit the use of anti-TNF- $a$ therapies in severe asthma. 


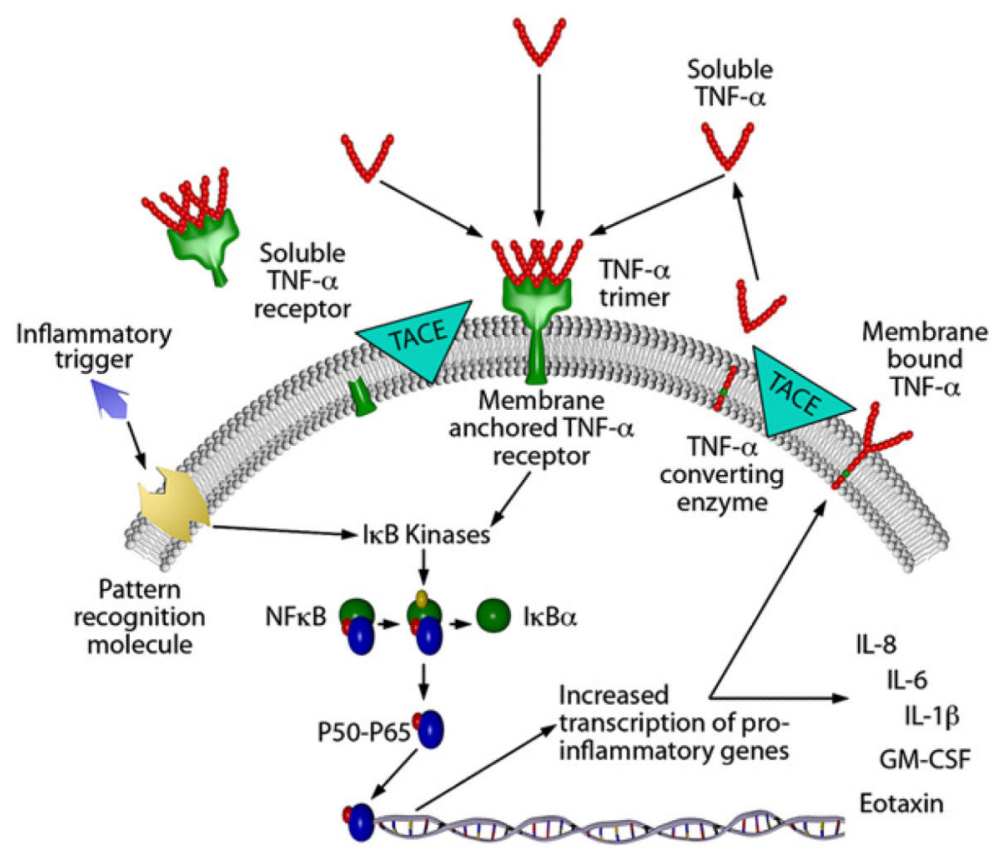

FIG 1.

Summary of TNF-a biology and signaling. The cascade of events involved in TNF-a signaling and receptor function is shown. See text for details. TACE, TNF-a-converting enzyme; $N F \kappa B$, nuclear factor $\kappa \mathrm{B}$. 


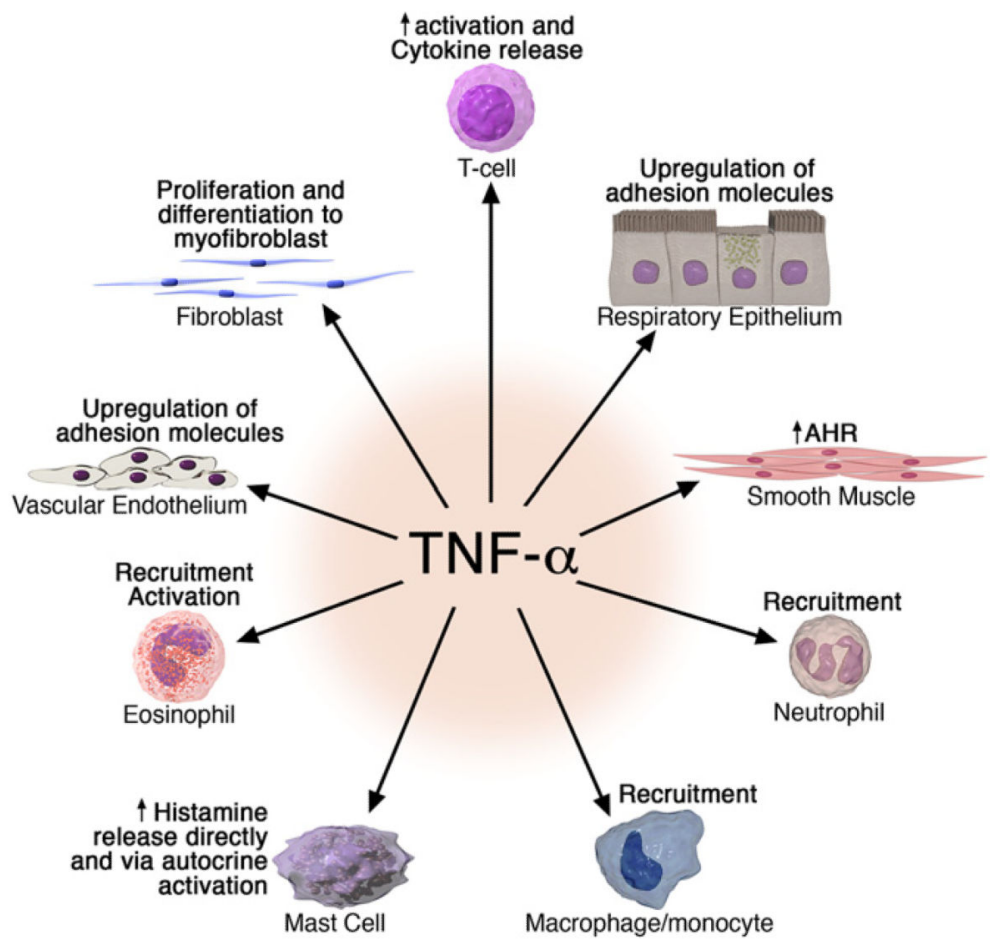

FIG 2.

Role of TNF- $a$ in the pathogenesis of asthma. TNF- $a$ plays a central role in many of the features of the asthma paradigm by exerting important effects on both inflammatory and structural cells. See text for details. 


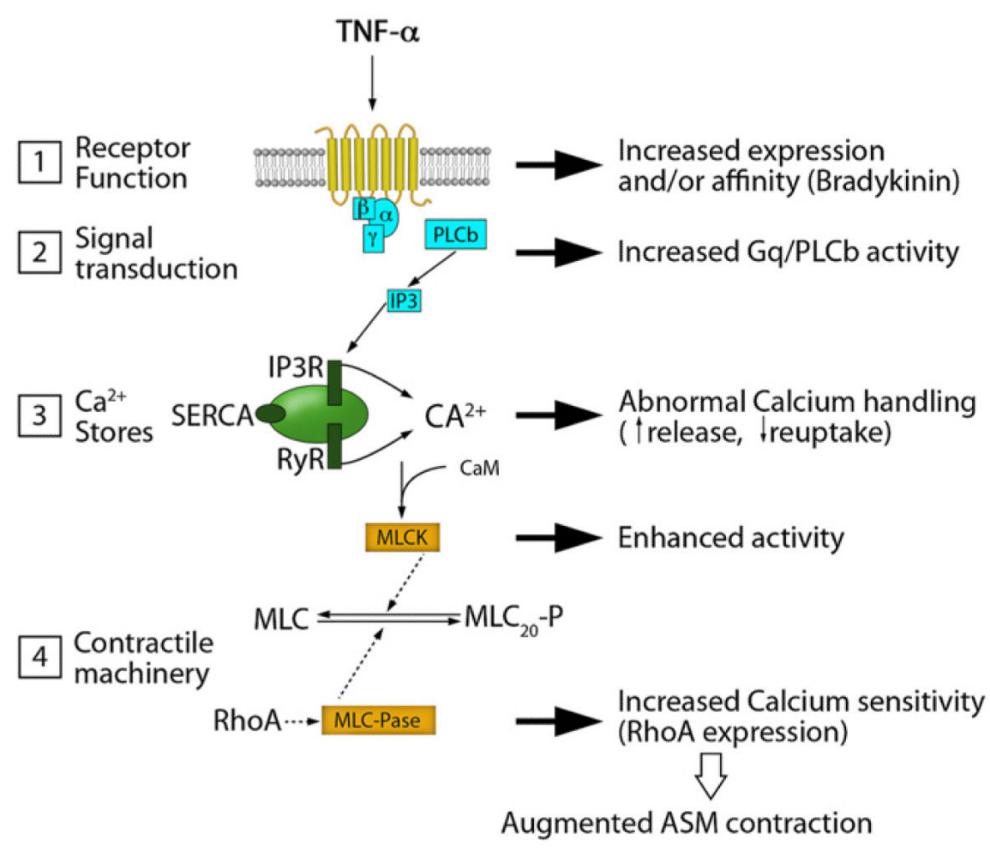

FIG 3.

Molecular mechanisms activated in ASM induced by TNF- $a$-activated molecular mechanisms in ASM possibly contributing to AHR in asthma. TNF-a might modulate AHR through a number of possible mechanisms: (1) enhanced receptor-associated calcium signals as a result of an increased expression, function, or both of the receptor $\mathrm{G}$ protein (Gaq or Gai); (2) altered signal transduction, such as increased phospholipase $\mathrm{C}$ (PLC $\beta$ ) expression, activity, or both; (3) abnormal calcium handling by exerting effects on key enzymes that regulate inositol-1,4,5-trisphosphate (IP3) metabolism, such as 5-phosphatase I and II, effects on function, and/or the expression of Ryanodine receptors $(R y R)$, IP3 receptor $(I P 3 R)$, or calcium ATPases called sarcoendoplasmic calcium ATPases (SERCA), which regulate calcium fluxes, or calmodulin $(\mathrm{CaM})$; and (4) changes in calcium sensitivity mediated by effects on RhoA expression or increases in both myosin light chain kinase $(M L C K)$ or myosin light chain phosphatase (Pase) content, activity, or both. See text for details. 
TABLE I

Summary of clinical trials of anti-TNF-a therapy in asthma

\begin{tabular}{|c|c|c|c|c|c|}
\hline & No./severity & Design & Treatment & Outcome & Result \\
\hline \multirow[t]{2}{*}{ Howarth et $\mathrm{al}^{7}$} & 15/GINA V & Open label uncontrolled & Etanercept 12 wk & $1^{\circ} \mathrm{ACQ}$ & $\begin{array}{l}\text { Improvement } \\
\text { ACQ, } \mathrm{FEV}_{1}, \mathrm{AHR}\end{array}$ \\
\hline & & & & $2^{\circ} \mathrm{FEV}_{1}, \mathrm{AHR}$ & \\
\hline \multirow[t]{2}{*}{ Berry et al ${ }^{8}$} & 10/7 GINA V, 3 GINA IV & $\begin{array}{l}\text { Randomized placebo } \\
\text { controlled crossover }\end{array}$ & Etanercept 10 wk & $\begin{array}{l}1^{\circ} \mathrm{AHR} \text { and } \\
\mathrm{AQLQ}\end{array}$ & $\begin{array}{l}\text { Improvement } \\
\text { AQLQ, FEV } \\
\text { AHR }\end{array}$ \\
\hline & & & & $\begin{array}{l}2^{\circ} \mathrm{FEV}_{1}, \\
\text { eNO, sputum } \\
\text { cell counts }\end{array}$ & $\downarrow$ sputum histamine \\
\hline \multirow[t]{2}{*}{ Morjaria et al ${ }^{61}$} & 39/21 GINA V, 18 GINA IV & $\begin{array}{l}\text { Randomized placebo } \\
\text { controlled parallel group }\end{array}$ & Etanercept 12 wk & $1^{\circ} \mathrm{AQLQ}$ & $\begin{array}{l}\text { No benefit } \\
\text { compared with } \\
\text { placebo }\end{array}$ \\
\hline & & & & $\begin{array}{l}2^{\circ} \mathrm{ACQ}, \\
\mathrm{FEV}_{1}, \mathrm{PEF}, \\
\text { AHR, } \\
\text { exacerbations }\end{array}$ & \\
\hline \multirow[t]{3}{*}{ Erin et $\mathrm{al}^{59}$} & 38/inhaled corticosteroids only & $\begin{array}{l}\text { Randomized placebo } \\
\text { controlled parallel group }\end{array}$ & Infliximab $6 \mathrm{wk}$ & $\begin{array}{l}1^{\circ} \text { morning } \\
\text { PEF }\end{array}$ & $\begin{array}{l}\text { No change in } \\
\text { morning PEF }\end{array}$ \\
\hline & & & & $\begin{array}{l}2^{\circ} \mathrm{FEV}_{1} \text {, } \\
\text { exacerbations, } \\
\text { sputum } \\
\text { markers }\end{array}$ & $\downarrow$ PEF variability \\
\hline & & & & & $\downarrow$, exacerbations \\
\hline Rouhani et $\mathrm{al}^{60}$ & $21 / \beta$-agonist only & Segmental allergen challenge & Etanercept 2 wk & $\begin{array}{l}\text { Markers of } \\
\text { inflammation } \\
\text { AHR }\end{array}$ & $\begin{array}{l}\text { Increased TNFR2 } \\
\text { in BAL, no change } \\
\text { in AHR }\end{array}$ \\
\hline
\end{tabular}

GINA, Global Initiative for Asthma; $1^{\circ}$, primary outcomes; $2^{\circ}$, secondary outcomes; $A C Q$, asthma control questionnaire; $A Q L Q$, asthma quality-oflife questionnaire; $e N O$, exhaled nitric oxide; $P E F$, peak expiratory flow; $B A L$, bronchoalveolar lavage; TNFR2, TNF receptor 2. 